\title{
Wounded Veterans and the State: The precursor of the veteran's home in Sweden (1560-1650)
}

Erik Petersson

\section{Linköping University Post Print}

\section{Tweet}

N.B.: When citing this work, cite the original article.

This is an electronic version of an article published in:

Erik Petersson, Wounded Veterans and the State: The precursor of the veteran's home in Sweden (1560-1650), 2014, Scandinavian Journal of History, (39), 2, 185-197.

Scandinavian Journal of History is available online at informaworldTM:

http://dx.doi.org/10.1080/03468755.2013.878749

Copyright: Taylor \& Francis (Routledge): SSH Titles

http://www.routledge.com/

Postprint available at: Linköping University Electronic Press

http://urn.kb.se/resolve?urn=urn:nbn:se:liu:diva-105387 
Erik Peterson, Linköping University

\title{
Wounded Veterans and the State
}

\author{
The Precursor of the Veteran's Home in Sweden (1560-1650)
}

\section{Introduction}

A hospital record dated 1647 from the town of Viborg in what was then the eastern part of Sweden reports that an inmate in the institution, Thomas Thomasson Hakulj, had struck the hospital warden. The hearings that followed the incident revealed that Thomas Thomasson thought that he had special privileges since he had been injured when serving in war. During his service his feet were badly frozen. The pain that he had suffered made him, as the records tell the story, 'lose his mind, and [he] could not control himself any longer'. ${ }^{1}$ Thomas Thomasson did not even admit that he had done anything wrong when he used violence against the hospital warden. His condition, as he explained it himself, was not caused by his own action. The war was to be blamed for it, not him. He should therefore not be held responsible for beating the hospital warden. This behavior, which would not have been accepted under other circumstances, was explained and put into context and placed in relationship to the sufferings that Thomas Thomasson had been forced to endure in the war.

Although the records explained Thomas Thomasson's actions as more acceptable since he had suffered during the war, this incident raises the question of whether this was a unique event or whether it tells something about the common conception of wounded soldiers in the 17th century. This article is an attempt to study injured soldiers and how and when the Swedish state began to organize special care for this group. The second question is linked to the first and will examine what forms of care the wounded soldiers were offered and how this was organized. ${ }^{2}$ The article starts with a brief discussion of the state and how its development was inseparable from the war and its needs in the early 1600 s. 


\section{The Military State and Care}

The early 16th century saw the rise of more centralized states in several areas in Europe. This was due to the fact that the church had lost much of its previous domination and power to the princes as a result of the ongoing Reformation. Charles Tilly regarded the strong state as having emerged as a result of war, and he claimed that wars were what ultimately made states. $^{3}$ As Francis Fukuyama has noted, this seems to be universally true. China became the first centralized state in the $4^{\text {th }}$ and 3 rd centuries BCE as a result of constant fighting between different princes and smaller kingdoms. ${ }^{4}$ The same evolution took place in Europe in the 16th and 17th centuries, and war was the ultimate force that speeded up centralization and bureaucratization in the process of creating the state. The constant fighting between the states in Europe made them compete and continually try to develop faster than their neighbors.

Sweden was an unlikely candidate to take up the competition for domination in northern Europe. In the beginning of the 17th century the country was sparsely populated and had only small cities. Most of its resources were unexploited. Yet, Sweden succeeded in turning this around in a couple of decades. Next to France, Sweden was the new superpower that signed the Treaty of Westphalia that ended the Thirty Years' War in 1648.

A number of historians thoroughly investigated this question in the 1970s and 1980s. Sven A Nilsson and Jan Lindegren pointed out that Sweden succeeded by using its limited resources as efficiently as possible, and that this laid the foundation for the transformation of the country. ${ }^{5}$ They have argued that Sweden developed as a military state that was organized to be able to fight distant wars overseas, especially in the Baltic area and in Germany. ${ }^{6}$ But none of this would have been possible if the state had not been supported by the majority of the people, and in the $17^{\text {th }}$ century the majority in Sweden was still made up of peasants. They represented at least 90 per cent of the population. ${ }^{7}$ This mobilization of the resources and how it was done has been the main issue for the research up until recently. As Lauro Martines has noted, the last few decades have shown a new social history of war that has asked new questions. Historians have started to broaden their research and have recently been more interested in for example "the conditions of the common soldier, and for the voices of civilians caught up in the tangles of war' ${ }^{8}$ But as Martines also mentions, the vast majority of research in these fields remains to be done, as we know little or nothing about for instance the care for wounded soldiers.

One of the specific characteristics of the Swedish state was its efficient control over the people. The priest was supposed to keep records on each inhabitant in his parish. This was 
done as part of a reform of the Swedish military system. Up until the 1520 s there had been no permanent army in Sweden and, as was the case in England, each war or conflict had to be dealt with by the king who utilized special measures. ${ }^{9}$ The military consisted of the cavalry supplied by the aristocracy, local assemblies of peasants to guard the frontiers and mercenaries who were mostly foreign. This system was changed by Gustavus Vasa, who began to conscript peasants who were always supposed to be prepared to fight a war, even abroad. ${ }^{10}$ These peasant soldiers were volunteers, and they were still complemented by mercenaries. ${ }^{11}$ This system continued until 1619, when Gustavus Adolphus made a major reform. It implied that every tenth adult male between 15 and 60 years of age was to be enrolled, and the only exception consisted of those men who lived on territory that belonged to noblemen. ${ }^{12}$ This system implied that every grown man could be enrolled in the system, but the state and the local communities had similar interests in enrolling those who were not yet firmly rooted in society. The vast majority of the enrolled were young men, often aged 15 to 25 , who had not yet married and who did not own their own farms. ${ }^{13}$

The new enrollment system started in the beginning of 1621, and in short time 14,700 men on foot and 3,125 on horseback were assembled and shipped to the Thirty Years' War. ${ }^{14}$ One year later, 6,000 of the men were dead, most having died of diseases that spread rapidly in the garrisons during winter. The high mortality rate meant that new soldiers had to be recruited. This new enrollment had to take place annually or at least every second year so that the regiments would not be reduced. In the century that followed c. 600,000 men were enrolled for military service, but only approximately 100,000 of these survived and returned home. ${ }^{15}$ Many of them were badly injured, physically or mentally, or both. They lost limbs and had lived many years with extreme violence as a part of everyday life. Many were old. How and when did the state recognize the problem of returning soldiers and their livelihood?

\section{Special Care of Wounded Soldiers}

The first traces of special organized state care for crown servants dates to the 1560s. In an instruction he issued King Erik XIV pointed out wounded soldiers as a group worthy of help. Those who "had been shot, and because of that are ill or else for their old age" were to be allowed to stay on the properties of the Crown. ${ }^{16}$ There they were to have food and beer for the rest of their lives, and in return they were to contribute with whatever work they were able to do. It seems to have been important that the soldier had been wounded by enemies or was 
old in order to qualify for help. This meant that soldiers who only had been sick did not have the same rights. These specific qualifications for help were repeated in numerous documents and were also put forward in letters from soldiers to the king as reasons why they should receive assistance.

In 1565 many more wounded soldiers returned to Stockholm. The Swedish-Danish War, called the Seven Years' War (1563-1570), was fought in the southern parts of Sweden and on the Baltic Sea. In one of the battles at sea the greatest ship in the Swedish fleet, Mars, was captured by the Danish and sank after a devastating explosion. Many soldiers were captured and injured, and as many as 168 soldiers received four marks each in compensation from the state. ${ }^{17}$ Once again it was stated that soldiers who had been wounded by the enemy should have priority over others. ${ }^{18}$

Sweden was one of the countries in Europe which adopted the new Lutheran faith during the $16^{\text {th }}$ century. This meant that the Crown strengthened its economic capacity and dominance in society at the expense of the Church. Since the early Middle Ages care of the sick and poor relief had been one of the top priorities for the Church. This changed with the Reformation as the Crown took over the hospitals that had been run by the Church. Despite this, the hospitals were one of the areas mentioned in the new canon for the church, which was accepted in 1571. In this document it was stated that different categories of people should be able to seek care in the hospitals. Those who had infectious diseases were to be separated from others, which included the 'blind, lame, shot, stabbed or stricken'. ${ }^{19}$

The church canon was in line with what was going on all over Europe at this time. Since prices had risen due to crop failures which followed many consecutive years of bad weather, the masses of poor had grown larger in Sweden, as well as in other parts of the continent. This was the case, especially in the north. In Sweden, Denmark and England there were major problems and inflation. This meant that the institutions that used to be sufficient to meet the needs of poor relief were overwhelmed. Restrictions were put on who was considered qualified to receive care. The deserving or non-deserving poor were separated in two different categories, and criteria where established to distinguish the one from the other. Otherwise the limited resources for poor relief would have been grossly overdrawn.

In this struggle for the right to poor relief one category was once again distinguished as more deserving than others. The injured soldiers could more or less count on the Crown when it came to care.

In the 1560s King Erik XIV also started to issue special letters to wounded soldiers, which granted the soldier priority to hospitals from which they would receive their livelihood. 
The king's letters became common in the decades that followed, and wounded soldiers can be found regularly in hospital records from this time. Erik XIV stated that '.. there [in the hospitals] His Majesty in particular had to provide a living for those who have been wounded by the enemy... ${ }^{20}$ This meant that the soldiers should be attended to first, and the other categories of care seekers had to wait in line. In the same document, the king also stressed that it was important that each person stayed where he or she belonged. When poverty became a major problem in Europe in the course of the 16th century, many people left their homes and tried to seek a living in the towns. ${ }^{21}$ This meant that the hospitals became crowded with people who did not belong to the city and had no right to poor relief. In order to deal with this problem, the king stated clearly that each parish should support its own poor. This did, however, not include the wounded soldiers. They were still granted support at the hospitals by means of the king's letters.

It seems that the special care that was granted crown servants, and especially injured soldiers, was widely accepted. In 1604 the hospital in Viborg in eastern Sweden supported nine "sick and lame crown servants". 22 This number had risen to 22 in 1621 and continued to increase. In 1623 there were certainly not more than 19, but a year later the records show that 25 wounded crown servants were in the hospital. In 1625 there were as many as 29 . The number of crown servants at the hospital in Viborg had tripled in just over twenty years, and this must reflect the rise in numbers of soldiers wounded in the war.

In the beginning of the 17th century many of the Swedish hospitals formalized their organization in hospital by-laws. This meant that the custom of giving special care to crown servants was articulated. One of the clauses stated that persons who had been 'of our enemies wounded in their limbs' should have priority over other care takers. ${ }^{23}$ This meant that the system that had been established in practice since the 1560s was now regulated, but hospital care must have been rather exclusive in comparison to the need for relief. Since the wars became more and more common and resulted in increased numbers of wounded soldiers, the need constantly grew.

In the beginning of Gustavus Adolphus' reign, in the 1610s, it became relatively common for wounded soldiers to receive help by means of special letters from the king. In 1616, for instance, there are several letters in the registers concerning soldiers who were granted help. Two soldiers, Henrik Jöransson and Anders Bengtsson, were 'so lame, that they could no longer be used at court or on any march or expedition, [and] we have we assigned them to Uppsala Castle, ordering that they should receive their livelihood...' ${ }^{24}$ These wounded soldiers should receive support at the king's castle in Uppsala and not at a hospital. It was 
common that soldiers either got to live in the king's castles or were given help in the form of extra grain. Four barrels of grain per year seems to have been the most common quantity given. $^{25}$

Wounded soldiers had been articulated as a group in special need of help from the $1560 \mathrm{~s}$ onward. It seems that the state, which in most cases was the king, recognized the problem that many soldiers had to support themselves and thought it plausible that the state should help these people and their families. Until the 1610s the assistance was unorganized and seems to have been ad hoc. When the enlistment system was carried out in the years following 1620 , this could no longer be the case. The state had to organize the help; the question is how this was done and what help the wounded soldiers received.

\section{The Veteran's Home and the Veteran's Fund}

In the 1630s several reports complained about large groups of people who were roaming around in the countryside without any occupation. The problem was not new, but the magnitude was. The large amount of wounded soldiers was also new. They had been relatively few until the 1620 s, but with the new enlistment system it meant that many of the enlisted soldiers were injured and returned unable to work again. After the death of King Gustavus Adolphus a regency for his young daughter Christina took over, and in 1638 instructions were written for the governors in the provinces about the situation. They were admonished to be aware of "the disorder which should be abolished that is much grumbled throughout the country: begging soldiers and mariners along with other drones are roaming from one province to the other and should be watched over'. ${ }^{26}$

The injured soldiers were not exclusively a social problem anymore. They had also become a threat to order and stability in society since they were too numerous to be ignored. In this situation, the king's letters were not enough to solve the problem with this category. Several representatives for the Church expressed fear that the limited space in the hospitals would be inundated by people with letters from the king, and the Church tried to exert pressure on the state to take care of the problem.

The first step towards more systematic help for wounded soldiers had already been taken by Gustavus Adolphus in 1622. He had established a 'donation book', where he exhorted people to donate money to the care for this especially vulnerable group. The king wrote that everyone, both from the nobility and lower strata, should donate as much as they could as 
good Christians. The money would help out those who "for the well-being of the nation, have become crippled, and they should have their bread in the Vadstena monastery."27 This was due to the 1620 decision to base the Swedish army more or less totally on enrolled soldiers. Many of the enrolled soldiers fled from their duties, and the "donation book" seems to have been one thing that the king thought could help alleviate this problem.

The action taken by Gustavus Adolphus meant that a fund was established that eventually could provide help for wounded soldiers. The foundation was provided by a donation of land from the Crown, and this was followed by more gifts from the Crown and noblemen in the years that followed. It was called the Veteran's Home Fund (krigsmanshuskassan), and it mostly gathered its resources in grain from the land. This formed the basic relief for the soldiers. But neither the fund nor the home were realized at that time, probably because the resources were still too limited to be able to cope with the growing demand for help.

Not only were the injured soldiers discussed during the 1620s; the main issue was the social problem with growing poverty. In 1620 the king proposed a major reorganization of the hospitals, which implied that only a few grand hospitals would remain. The clergymen were asked to give their opinion about this plan, but they were not convinced that this change would solve the real problem. In their opinion the problem had its origins in the disorder that the people who traveled from town to town brought with them to the parishes:

So now severe disorder has come due to the never-ending begging that severely disturbs the peasantry, both in towns and in the countryside, of children, sick, lame, poor, and mariners and soldiers, who roam around the countryside and who are not pleased with what good people give to them. ${ }^{28}$

It is possible that the king listened to the clergymen; what remains a fact is that the proposal was never realized. A few years later, in 1624, a statute regarding begging was instead launched in order to address the problem with poverty. The Veteran's Home was mentioned as one of two special projects for certain categories of poor, namely wounded soldiers and orphans. ${ }^{29}$ This reveals that the Veteran's Home was now part of the plan for the organization of poor relief, but it would be years before the institution could start to operate.

In 1630 Sweden became involved in the Thirty Years' War, and just two years later King Gustavus Adolphus died at the Battle of Lützen. The war meant that the resources that Sweden had, both natural assets and people, were stretched to the utmost. This, in turn, was 
followed by a rapidly growing number of wounded soldiers who returned home to Sweden in the mid-1630s. The problem reached the chamber of the Privy Council and the custodians of the realm who shared power during the regency after the king's death. After some debates it was decided that a part of the tithe that usually was used to support the translation and distribution of Bibles would be granted instead to the Veteran's Home Fund..$^{30}$ This meant that the fund had a stable and regular income, and it seems that it was this decision that placed the economy of the institution on firm ground. Not long afterward the Veteran's Home in Vadstena could finally open, approximately 15 years after Gustavus Adolphus had established the 'donation book'.

In March 1638 Måns Andersson was contracted to become bookkeeper of the Veteran's Home in Vadstena. The town of Vadstena is in south-central Sweden near the lake Vättern and was thus strategically located from a geographical point of view. A Veteran's Home was also supposed to be established in the western part of Sweden and one in the eastern part of the Swedish Realm (Finland), but the promise of this second home was never to be fulfilled. Måns Andersson's task was to manage the records of the Veteran's Home and also to be in charge of the complex rebuilding of the old monastery.

The renovation of the northern structure in the monastery started in 1638 , but no records were saved from that year's work. The next year, the royal architect, Simon De la Vallée, was sent to Vadstena, and he made a proposal for how the buildings should be reconstructed. ${ }^{31}$ When the summer of 1640 arrived, De la Vallée's drawings seem to have been finished, and it is likely that the work on the buildings followed his plans. As he had been appointed royal architect, the role had been strengthened, and it was stipulated that no major rebuilding projects financed by the state should begin before a drawing by his hand was finished. ${ }^{32}$ Today De la Vallée's drawings are probably lost. ${ }^{33}$ Other records of the work have been retained and can provide information about the rebuilding project.

The first records preserved are from 1639, and they contain an incoming balance from the year before. ${ }^{34}$ This indicates that the rebuilding started in 1638. Salaries were paid to carpenters, glaziers, blacksmiths, stonecutters, masons and coppersmiths for the work they had done. The carpenters were paid most, 55 daler and 6 öre, while the masons and coppersmiths were paid 36 daler altogether. The types of work they had done were not specified, but another note in the records states that 79 windows had been produced, as well as a number of small tables and a staircase for one of the buildings.

The rebuilding of the monastery structures continued in the summer of 1640. At this point a brickyard had been started, and this meant that the bricklaying could be speeded up. Some 
old walls were also torn down, and the bricks from these were used for the rebuilding, especially in the western part of the Veteran's Home. In the early 1640s the northern building was ready for the first wounded soldiers to move in.

In the years after 1640 the central organization that was responsible for the newly opened Veteran's Home, the War College (krigskollegium), received numerous applications from officers who supported the requests of injured soldiers from their regiments. One of these applications mentions a soldier, Sven Håkansson, who was awarded help in a letter dated January 1643. This letter indicated that Sven Håkansson had been on duty for a long time, nearly thirty years, and he had eventually been injured. The letter states that he should either have a place in the Veteran's Home or be given help from the Veteran's Home Fund. He was not given a place in the institution, but was to receive five barrels of grain annually.

The following years the Veteran's Home in Vadstena was filled with injured soldiers. Beginning in February 1640 the commander at Vadstena Castle, Claude de Laval, was asked to give an annual account of the numbers housed in the home. In 1644, only four years after the first soldiers had moved in, the number was already 26, and all of them had their families with them. Fifteen of these were common soldiers, and eleven were higher officers. All of them were married, and they had a total of 27 children. ${ }^{35}$

The number of places in the Veteran's Home was limited by its fixed number of rooms in the old monastery. Approximately 25 to 30 families could live there, and it seems that the injured soldiers usually lived there for a few years, some wounded soldiers even for decades. Per Jönsson, for example, was assigned a place in the home in 1642, and he still lived there in $1666 .^{36}$ When they died, the widows and their children could stay on in the home for another year, after which time they were expected to remarry and form a new household. It is obvious that the limited number of places in the Veteran's Home never should meet the demand for help, since we know that thousands of soldiers returned home during the 1600s. What, then, was the purpose of having the Veteran's Home if it could support only a few of all wounded soldiers that needed help? One possible answer is that the Home could serve a purpose mainly as a rhetorical figure for the King. If the Estates complained on the burdens of the enlistment he could always argue that the State supported those who were wounded since there was a Veteran's Home for them. If this was the case, it did not matter that much that the institution in no way had the means to support more than a few percent of the wounded soldiers. Another possible explanation is that the Veteran's Home was intended only for the soldiers that had been badly wounded, and that could not return to their home parishes. Either way, the limited 
number of places in the Veteran's Home suggests that the State was not that interested in helping the wounded soldiers out. ${ }^{37}$

In the beginning of the 1640s, when the Veteran's Home in Vadstena had started to operate, the situation in the eastern part of the Swedish Realm was much discussed. It was stated in Gustavus Adolphus' plan that a Veteran's Home should also be started in this part of Sweden, but nothing was done to bring this idea to fruition. This meant that the wounded soldiers in the east still had to rely on the king's letters in order to get poor relief. ${ }^{38}$

In 1643 the bishop in Viborg wrote about the situation in his episcopate. In his opinion, most care takers in the hospital were disabled soldiers, 'some of them lame, some of them old castle servants'. ${ }^{39}$ This meant that the hospital's scarce resources could no longer support all of those in need of poor relief in the episcopate. The bishop obviously did not think that the wounded soldiers and other crown servants belonged in the hospital. He also said that if all crown servants who wanted help were accepted at the hospital, 'no other poor could receive any help ${ }^{40}$ It is obvious that the Church tried to categorize the wounded soldiers as a group that should not dwell in the crown hospitals, and this was especially true after the opening of the Veteran's Home and the establishment of the fund. In 1644 the regency promised the Church that wounded warriors would no longer receive the king's letters admitting them to the hospitals. Instead, the soldiers were granted a place in the Veteran's Home or grain from the Veteran's Home Fund. ${ }^{41}$ The implications of the document were that the state would help wounded soldiers and that it was ready to take action to help those in this category to procure their livelihood. However, as was the case with the 1622 establishment of the 'donation book', the document shows the intention concerning the organization of help for wounded soldiers. In reality, however, this was not always the case. Wounded soldiers still remained a problem for the state, but at least it had recognized them as a group worthy of help and tried to provide a few of them with a roof over their heads and something to eat.

\section{Conclusion}

The wounded soldiers were first designated as a category worthy of special poor relief in the 1560s. During the decades that followed, they could receive letters from the king that promised either a place at a hospital or on an estate owned by the Crown. An alternative was receiving annual help in the form of some barrels of grain. This system worked up until the 1610 s, when it was gradually transformed into a more organized form of assistance. The 
organization of poor relief for soldiers was started by Gustavus Adolphus in 1622, when he opened a 'donation book' to gather resources for this purpose. In 1640 the Veteran's Home in Vadstena was opened, and it was the most extensive project that the state initiated to deal with old and wounded soldiers. Between 25 and 30 soldiers and their families in need of relief were allowed to live there. This group was obviously considered worth a major investment according to the state, despite the fact that these men were never likely to serve in war again. This fact makes the commitment from the state in the Veteran's Home and the fund project even more interesting, since these projects seem to have involved only relief. The state obviously had motives other than pure profit and the maximum extraction of resources; it thus gave something back to those who made sacrifices. The condition for granting help was that one had to have been wounded by the enemy. In the eyes of the contemporary world these men had sacrificed something for the state and should therefore be helped.

The Veteran's Home is one of two examples in Sweden where the state was an active care giver; the other example was the orphanage in Stockholm founded in 1633. The state invested resources in something that today could be called a social project, where the relief and well-being of the old and wounded were more important than making them fit for service again. It is an example of what Annika Sandén has pointed out: in the early modern period the Swedish state also dealt with what we today call welfare. ${ }^{42}$ The Veteran's Home and the fund were to help the wounded soldiers, and at the same time help the surrounding society. It reduced the numbers of wounded soldiers roaming around as beggars. The Swedish example of the Veteran's Home is striking both as an early and far-reaching project even in an international perspective. In France Henric IV started the Maison Royale de la Charité chrétienne in 1611 , but it was closed after only a few years. ${ }^{43}$ The great L'Hotel des Invalides in Paris was not opened until the 1670s in Ludwig XIV's era.

The connection between the enrollment system and the Veteran's Home and Fund should be emphasized. In the long run the organization of the military defined the Swedish state as it took form in the 1600s. This meant that the military and its needs formed the foundation for the other parts of the bureaucratization process. The Veteran's Home and Fund was one of the consequences of the special Swedish system of enrolling soldiers. When they were torn from their environment, most often from their farms in their parishes, the king was responsible for them if they returned from war old or wounded, and it was the state that started to organize help for them starting in the 1620s. 
${ }^{1}$ Fagerlund, Finlands leprosorier 2. Maria Magdalenae, Wiborgs hospital, 52: "[...] Vndertijdhen blifuet hufuudwill, och kan intet mehra styra sigh".

${ }^{2}$ This article is part of my thesis project at Linköping University called The Wounded Soldiers of the Great Power: State, Care and Power-legitimization in Early Modern Sweden (will be published at the end of 2014), where the questions in this article is more thoroughly discussed.

${ }^{3}$ Tilly, Coercion, Capital, and European States, ad 990-1992, 67-68, 70-76

${ }^{4}$ Fukuyama, The Origins of Political Order, 110-115

${ }^{5}$ Sven A Nilsson's research project was called Sociala och statsfinansiella problem i 1600-talets samhälle. Jan Lindegren in, Johansson \& Björk, Svenska historiker, ed, 618-619

${ }^{6}$ Lindegren, "The Swedish 'Military State', 1560-1720", Scandinavian Journal of History, 330-332

${ }^{7}$ Lindegren, 309

${ }^{8}$ Lauro Martines, Furies: War in Europe 1450-1700, xiv

${ }^{9}$ Hudson, The English Privy Council and Relief of Disabled Soldiers, circa 1558-1625, 241

${ }^{10}$ Larsson, "Gustav Vasa och den nationella hären", 252

${ }^{11}$ Nilsson, De stora krigens tid, 152-155

${ }^{12}$ Huhtamies, Knektar och bönder, 39

${ }^{13}$ Lindegren, Utskrivning och utsugning, 151

${ }^{14}$ Norberg, Polen i svensk politik 1617-1626, 119

${ }^{15}$ Forssberg, Att hålla folket på gott humör, 16

${ }^{16}$ Handlingar rörande Skandinaviens historia 27, 39

${ }^{17}$ Lager-Kromnow, Att vara Stockholmare på 1560-talet, 199

${ }^{18}$ Handlingar rörande Skandinaviens historia 27, 89

${ }^{19}$ Kjöllerström, 1571 års kyrkoordning, 197: "blinde, halte, skottne, hugne eller slagne"

${ }^{20}$ Sandholm, Kyrkan och hospitalshjonen, 174: "ther K. Maj. haffuer synnerligen förordnedt theres vnderhåld, som för Rigzens Fiender någenn schade lidit haffue ..."

${ }^{21}$ Lis \& Soly, Fattigdom och kapitalism i det förindustriella Europa, 119-122

${ }^{22}$ Sandholm, 175: "siuke och förlammede kronones tienare".

${ }^{23}$ Sandholm, 174: "af wåra fiender skåmfererats uti deras lemmar".

${ }^{24}$ Riksregistraturen 23 May 1616

${ }^{25}$ For example: Mats Larsson, Riksregistraturen 24 July 1616; Måns Torstensson, Riksregistraturen 12 August 1616

${ }^{26}$ Levander, Fattigt folk och tiggare, 98: "den oordning som klagas mycket vara i landet, med tiggeri av knektar och båtsmän, avställes [avskaffas], och att detsamma med andra lättingar, de där stryka utur den ena provinsen i den andra, tages i akt."

${ }^{27}$ Krigsarkivet, D XXV vol 67, Avskrifter av donationsbrev, 30 July 1622: "för fäderneslandzens välfärd, illa förlammade äre, och theras brödh haffua skola i Wastena Closter."

${ }^{28}$ Thyselius, 20: "Så ähr och een swår Oordning inkommen, af thett oeendelige Tiggerij, som Almogen swårligen beswärar, både j Städerna och på Landzbygden, af Barn, Siuka, förlammadhe, Huussarna, sammaledes Båtzmänn och knechter, som och myckett löpa om Land, och icke giärna ähre till fridz, medh thett, gått Folck them gifwer."

${ }^{29} \mathrm{Ibid}, 44-45$

${ }^{30}$ Svenska riksrådets protokoll 1635

${ }^{31}$ Riksregistraturen, 19 mars 1639 , fol. 248

${ }^{32}$ Riksregistraturen, 9 mars 1639, fol. 176

${ }^{33}$ Even if Sten Karling claims that they are in the archive of Riddarhuset, Karling, "Simon De la Vallée och Vadstena krigsmanshus", 143-154

${ }^{34}$ Kammararkivet, Kyrko-, skol- och hospitalsräkenskaper, vol 38, fol. 1-24

${ }^{35}$ Krigskollegium, Krigsmanshuskontoret: Verifikationer till huvudböckerna, 1641-1644

${ }^{36}$ Bergström, Vadstena krigsmanshus: Personhistoriska anteckningar, 30

${ }^{37}$ The difference between the limits of the Veteran's Home and the far greater need is more thoroughly discussed in the thesis.

${ }^{38}$ The situation in Finland seems to have been improved, but the idea that the eastern part should have its own Veteran's home was now and then on the table. As late as in the years around 1680 this question was still present. 


\footnotetext{
39 Sandholm, 175: "Sombliga förlammade, och ehn deel gamble Slotztienare."

${ }^{40}$ Sandholm, 176: "så kunne inga andra fattighe bliffua hullpne."

${ }^{41}$ Sandholm, 176

${ }^{42}$ Sandén, Stadsgemenskapens resurser och villkor, 13-19

${ }^{43}$ McMurtrie, The Disabled Soldier, 16
}

\section{References}

\section{Primal sources}

The Military Archives (Krigsarkivet)

Krigskollegium, Krigsmanshuskontoret

D XXV, vol. 67, Avskrifter av donationsbrev

Verifikationer till huvudböckerna, 1641-1644

The National Archives (Riksarkivet)

Kammararkivet, Kyrko-, skol-, och hospitalsräkenskaper, vol. 38, Specialräkenskaper för

Vadstena krigsmanshus 1639-1640

Riksregistraturen:

23 May, 24 July, 12 August 1616

9, 19 March 1639

\section{Printed sources}

Hall, B Rud. Johannes Rudbeckius dagbok. Stockholm: Svenska kyrkans diakonistyrelses bokförlag, 1938.

Handlingar rörande Skandinaviens historia 27: "Instruction ställt för then Stormechtigeste Högborne Furstes och Herres Her Erickz then Fiortonde [...] the såsom i Stockholm vti högbe:te Kong. M:ttz fråwaru tillstädes blifwa schole etc", 1st of November 1563.

Holmström, Otto. Ärkebiskop Abrahams räfst. Efter originalakterna. 2 vols. Uppsala: Wretmans tryckeri, 1901-1902.

Kjöllerström, Sven. Den svenska kyrkoordningen 1571. Jämte studier kring tillkomst, innehåll och användning. Lund: 1971. 
Svenska riksrådets protokoll 5, 1635. Stockholm: 1888.

Thyselius, Pehr Erik. 'Uppå Kongl. Maj:ttz wår allernådigste Herress och Konungz framställte Punchter om Academiens, Scholerss och Hospitalerss reformation Prästerskapzenss enfaldige Betenckiandhe. Actum Stockholm, denn 20 Martii Åhr 1620', printed in Handlingar rörande svenska kyrkans och läroverkens historia I. Örebro: 1839.

\section{Literature}

Ailes, Mary Elizabeth. Military Migration and State Formation. The British Military Community in 17th-Century Sweden. Lincoln: University of Nebraska Press, 2002. Bergström, Otto. Vadstena krigsmanshus: Personhistoriska anteckningar. Stockholm: Norstedts, 1901.

Collstedt, Christopher. Våldets väsen: Synen på militärers våld mot civilbefolkning i 1600talets Sverige. Lund: Sekel förlag, 2012.

Fagerlund, Lars Wilhlem. Finlands leprosorier 2. Helsingfors, 1901

Forssberg, Anna-Maria. Att hålla folket på gott humör: Informationsspridning, krigspropaganda och mobilisering $i$ Sverige 1655-1680. Acta Universitatis Stockholmiensis. Stockholm Studies in History 80. Stockholm: Almqvist \& Wiksell, 2005.

Fukuyama, Francis. The Origins of Political Order: From Prehuman Times to the French Revolution. London: Profile Books, 2011.

Gerber, David A, ed. Disabled Veterans in History. Madison: The University of Michigan Press, 2000.

Hudson, Geoffrey Lewis. The English Privy Council and Relief of Disabled Soldiers, circa 1558-1625. McMaster University, 1988.

Huhtamies, Mikko. Knektar och bönder. Knektersättare vid utskrivningarna i Nedre Satakunda under trettioåriga kriget. Helsingfors: Svenska litteratursällskapet i Finland, 2004.

Karling, Sten. 'Simon De la Vallée och Vadstena krigsmanshus'. Kulturspeglingar (1966): 143-154.

Klockhoff, Axel. Danviks hospital. Vols. 1-2, Dess rättsliga ställning. Uppsala: Almqvist \& Wiksells boktryckeri, 1935-1936. 
Lager-Kromnow, Birgitta. Att vara Stockholmare på 1560-talet. Stockholm: Almqvist \& Wiksell tryckeri, 1992.

Larsson, Lars-Olof. 'Gustav Vasa och ”den nationella hären” ', Scandia 33 (1967): 250-269.

Levander, Lars. Fattigt folk och tiggare. Stockholm: Åhlén och söners bokförlag, 1934.

Lindegren, Jan. Utskrivning och utsugning: Produktion och reproduktion i Bygdeå 16201640. Acta Universitatis Upsaliensis. Studia Historica Upsaliensia 117. Stockholm: Almqvist \& Wiksell, 1980.

Lindegren, Jan. 'The Swedish “Military State”, 1560-1720', Scandinavian Journal of History, 1985:10

Lis, Catharina \& Soly, Hugo. Fattigdom och kapitalism i det förindustriella Europa. Göteborg: Röda bokförlaget, 1982.

Martines, Lauro. Furies: War in Europe 1450-1700. New York: Bloomsbury Press, 2013. McMurtrie, Douglas C. The Disabled Soldiers. New York: The Macmillan Company, 191

Nilsson, Sven A. De stora krigens tid: Om Sverige som militärstat och bondesamhälle. Acta Universitatis Upsaliensis. Studia Historica Upsaliensia 161. Stockholm: Almqvist \& Wiksell International, 1990.

Norberg, Axel. Polen i svensk politik 1617-1626. Stockholm: Almqvist \& Wiksell, 1974.

Sandén, Annika. Stadsgemenskapens resurser och villkor: Samhällssyn och välfärdsstrategier i Linköping 1600-1620. Linköping Studies in Arts and Science. 330. Linköping:

Linköping University Press, 2005.

Sandholm, Åke. Kyrkan och hospitalshjonen: En undersökning rörande omsorgen om de sjuka och fattiga $i$ välfärdsanstalterna i Finland. Helsingfors: Finska kyrkohistoriska samfundet, 1973.

Sjöberg, Maria, Kvinnor i fält 1550-1850. Möklinta: Gidlunds, 2008.

Tilly, Charles. Coercion, Capital, and European States, AD 990-1992. Oxford: Blackwell Publishing, 1992.

Westling, Gottfrid. Ur Linköpings stifts historia 1593-1843. Linköping: Östgöta Correspondentens boktryckeri, 1919.

Erik Petersson (1985) is a PhD student at Linköping University. He is currently working on a thesis dealing with the care for wounded soldiers in the $17^{\text {th }}$ century and the veteran's home in 
Vadstena. His main research interests are state formation and the role of the individual in history. Adress: Department for Studies of Social Change and Culture - ISAK, Linköping

University, Linköping, SE 581 83, Sweden. [email: erik.petersson@liu.se] 